\title{
II. RESENHAS DE LIVROS
}

Boccalandro, Marina. (2020). Qualidades Positivas: benefícios para sua vida. São Paulo: Paco Editorial.

A autora desta obra é a psicóloga clínica, psicoterapeuta Marina Pereira Rojas Boccalandro, doutora e mestre em Psicologia Clínica, bacharel, licenciada e graduada pela PUC/SP. Em 1957, iniciou sua vida profissional no Instituto de Psiquiatria da Faculdade de Medicina da USP, onde permaneceu até 1977. A partir desta data ingressou no quadro de Professores na PUC/SP, tendo se aposentado em 2018. Autora de vários artigos científicos publicados em revistas nacionais e estrangeiras e de capítulos sobre a área que atua. Autora dos livros: Sob o Domínio de Pã(nico): Um estudo do Transtorno de Pânico através da Psicossíntese e As virtudes na psicoterapia e na qualidade de vida. Na introdução deste livro e no primeiro capítulo a autora expressa sua necessidade em comunicar a importância das qualidades positivas na vida dos indivíduos, bem como as virtudes que as acompanham. Com base na teoria da Psicossíntese, criada por Roberto Assagioli, no início do século passado, um psicólogo positivo, humanista e transpessoal, Boccalandro aborda sete qualidades, gratidão, felicidade, otimismo, generosidade, criatividade, coragem e interação social. A Psicologia Humanista combina aspectos do existencialismo e do humanismo de um modo que reconhece a contribuição das abordagens da "Primeira Força", o Behaviorismo ou Psicologia Comportamental, que estuda as relações entre estimulo e resposta, condicionamento/descondicionamento desenvolvidas por Pavlov, Watson e B. Skinner. A "Segunda Força" é a Psicanálise de S. Freud, M.Klein, J. Lacan e D.W. Winnicott que através de teorias psicológicas e psicopatológicas baseiam o processo psicoterápico pela interpretação da resistência, da transferência e do desejo. A “Terceira Força”, a Psicologia Humanista (e Existencial), controversa as duas forças anteriores, critica a postura mecanicista, determinista, fatalista, patologizante e reducionista, sem negar sua contribuição. Para Assagioli (1973) o que diferencia a psicologia humanista das psicologias anteriores são: o estudo da natureza e da qualidade do ser humano sadio e particularmente de seus melhores aspectos (qualidades); a descoberta das potencialidades latentes; o desenvolvimento e o uso de técnicas para manifestar essas potencialidades e colocá-las em ação em todos os campos da vida e das atividades humanas, diz a autora. A "Quarta Força”, a Psicologia Transpessoal, tem por objetivo expandir o campo da pesquisa psicológica, incluindo áreas da experiência e do comportamento humano associado a transcendência, estudando a consciência em si e seus estados alterados e transpessoais. Como representantes estão Stanislav Grof, Kem Wilber, Maslow, Sutich, Tart, P. Weil, F. Capra, antecedidos por Jung, dentre outros. A autora apresenta, ainda, a Psicologia humanista, a Psicologia positiva e a Psicologia transpessoal com suas principais características e diferenciações, bem como seus principais representantes de forma sucinta, mas esclarecedora. No capítulo 2, Boccalandro (2020), nos fala da abordagem Psicossíntese enquanto teoria e técnica psicológica, da cartografia da consciência, segundo Assagioli, fundamentos do ser e conceitos básicos ao qual está alicerçada; as subpersonalidades, identificação-desidentificação e vontade. Neste capitulo, contamos ainda com exercício prático, Exercício Jardim Interno, uma técnica que visa levar o indivíduo a meditar e entrar em contato com o Self, ou Eu Superior, o Centro do Nosso Ser. No capítulo 3, a autora discorre sobre a Gratidão, umas das qualidades positivas, conceituando, contextualizando, fundamentando e exemplificando todas as potencialidades da utilização dessa qualidade. Demonstra de que forma pode ser utilizada, apresentando casos, exercícios e poesias com o tema. No capítulo 4, Felicidade, Boccalandro inicia com uma linda poesia (Medeiros, 2012), discorre sobre as diversas definições sobre o tema e suas peculiaridades de acordo com as tradições de cada sociedade. Sugere alguns exercícios que tem como objetivo autoconhecimento, criatividade, (re)vivência de memórias positivas, gratidão e emoções positivas. O capítulo 5, Otimismo, conta com a apresentação de vários estudos científicos da atualidade, onde diversos estudiosos demonstram sua importância

${ }^{50}$ Psicóloga Clínica. Contato: Avenida da Invernada, 432-203 - Campo Belo- CEP 04612-061 - São Paulo, SP. E-mail: criscarrieri@gmail.com. ORCID https:/lorcid. org/0000-0003-0722-8705. 
na vida das pessoas provocando um melhor desempenho no trabalho, nos estudos, nos relacionamentos e no enfrentamento de momentos difíceis na vida. Apresenta casos, exercícios e poesias sobre o tema. O capítulo 6, diz respeito a Generosidade, uma qualidade mais ligada ao altruísmo que faz uma pessoa agir de modo a conciliar sua satisfação pessoal com o bem-estar e a satisfação de seus semelhantes, de sua família, do seu trabalho e de sua comunidade, indicando que o ser humano pode ser bom e generoso naturalmente. Além de poemas, algumas dicas para desenvolver a generosidade e uma pequena história do livro A Jornada Sagrada do Guerreiro Pacifico. (Millman, 2009). No capítulo 7, Criatividade, além das diversas definições encontradas para este constructo, por várias correntes, a autora a caracteriza segundo a psicologia humanista e sua ligação com o inconsciente superior, do próprio Self e até do inconsciente coletivo. Apresenta exercício para um maior desenvolvimento da criatividade e mudança, além de uma bela poesia de Olympiades Guimarães Corrêa. A Coragem é abordada no capítulo 8, outra qualidade importante para o desenvolvimento da personalidade. Na psicoterapia é um constructo muito importante, diretamente ligado ao sucesso do processo, pois segundo a autora quando este aspecto é positivo ele é encontrado no inconsciente superior, no lado saudável do ser humano, mas pode ser negativo, geralmente ligado a uma desordem psiquiátrica ou psicológica e é encontrado no inconsciente inferior. A autora mostra a forma que podemos utilizar essa virtude ajudando as pessoas a confrontar-se com os desafios da vida através de exercício para desenvolver a coragem. $\mathrm{O}$ capítulo 9, Interação Social, é seu capítulo mais extenso e está dividido em quatro partes: 1) Relacionamento na Infância; 2) Relacionamento na adolescência; 3) Relacionamento na fase adulta; 4) Relacionamento na envelhescência e velhice. A partir da conceituação de Interação Social, caracterizando o homem enquanto ser humano que vive em sociedade e em processo dinâmico e evolutivo a autora nos traz desde os tempos mais remotos, como os dos índios norte-americanos, com o seu Código de ética, que vivem como uma grande fraternidade até estudos recentes de Seligman(2004), Portella (2013) e Assagioli (2014). Boccalandro destaca o Relacionamento na Infância como cruciais para a formação de uma base sólida para o desenvolvimento físico e emocional da criança. Apresenta estudo de caso acompanhado de seu respectivo tratamento, passos da técnica Shantala, bem como seus benefícios. O Relacionamento na adolescência para a autora é bastante complexo exigindo maior sabedoria interna, tanto do ponto de vista físico, como emocional e mental, assim, sugere algumas técnicas, bem como relata casos clínicos que ajudam tanto terapeutas quanto amigos e familiares a lidarem com este público. Relacionamento na fase adulta segundo a autora é um processo dinâmico e em constante transformação, nesta etapa ela descreve as principais mudanças e as características dessa fase. Apresenta exercício e caso clínico para melhor elucidação. Relacionamento na envelhescência e velhice a autora aborda o processo de forma natural, dinâmica, progressiva e irreversível, trazendo esclarecimentos sobre como se manter ativo, calmo e sereno diante de mais esse desafio. Neste, como em todos os capítulos encontramos sempre pelo menos um exercício, uma poesia e um estudo de caso para elucidar os aspectos teóricos abordados.

Elegi a FELICIDADE para expressar o meu sentimento ao concluir este trabalho.

Ser feliz é encontrar força no perdão, esperança nas batalhas,

segurança no palco do medo, amor nos desencontros...

Ser feliz é reconhecer que vale a pena viver a vida, apesar de

todos os desafios, incompreensões e períodos de crise...

Ser feliz é deixar de ser vítima dos problemas e se tornar ator

da própria história....

Ser feliz é deixar viver a criança livre, alegre e simples, que vive dentro de cada um de nós....

Ser feliz é agradecer a Deus cada manhã pelo milagre da vida.

(Medeiros, 2012)

Um livro destinado a psicoterapeutas, profissionais da área da saúde, adultos, jovens ou idosos, que buscam autoconhecimento como pessoa, individualmente, socialmente e espiritualmente. 